\title{
PROFESSIONAL OPINIONS AND ATTITUDES ON TAX POLICY IN BOSNIA AND HERZEGOVINA WITH A SPECIAL FOCUS ON THE FEDERATION OF BOSNIA AND HERZEGOVINA ${ }^{1}$
}

Lejla Lazović-Pita, Ana Štambuk

\section{Abstract}

This research is based on tax policy opinion survey data collected in Bosnia and Herzegovina (B\&H) among tax experts. A special focus of the survey was to investigate the consequences of the different institutional environments that exist between the two entities of the country. After having reviewed all previous tax reforms in $B \& H$, the most interesting results suggest that respondents agree on the introduction of a progressive personal income tax (PIT) and excise duty on luxury products, the maintenance of personal and family allowances and the maintenance of the current value added tax (VAT) and corporate income tax (CIT) rates. However, differences exist in the respondents' perceptions about the introduction of reduced VAT rates, the regressivity of the VAT, and giving priority to the equity principle over the efficiency principle in taxation. Probability modelling highlighted these differences and indicated inconsistencies in the definition of the PIT tax base, namely the comprehensiveness of the PIT base under the S-H-S definition of income.

Keywords: opinion survey, tax policy, tax reform, $B \& H$

JEL: $H 20$

\section{INTRODUCTION}

Since the 1970s and the outbreak of neo-liberal economic thought induced by globalisation, the tax policies of developed countries have mostly been tailored to respond to changes in macroeconomic government. Thus, in developed countries (mostly those of the European Union (hereafter: EU) and OECD members), tax policy has aimed at fulfilling the following objectives: shifting taxation away from labour towards consumption, broadening the income and consumption tax base, reducing the number and the size of income tax rates (personal income tax (hereafter: PIT) and corporate income tax (hereafter: CIT)), and improving tax compliance. These objectives are also more recent suggestions and recommendations from the OECD (2010) and the European Commission (Garnier et al. 2013). With the outbreak of the global financial crisis (hereafter: GFC) in 2008-2009, which brought the more profound problems of budget deficits (EUROSTAT 2013), the suggestions and recommendations for all EU members (i.e., developed and

Lejla Lazović-Pita, MSc
Teaching Assistant
School of Economics and Business,
University of Sarajevo
E-mail: lejla.lazovic@efsa.unsa.ba
Ana Štambuk, PhD
Assistant Professor
Faculty of Economics, University of Rijeka
E-mail: ana@efri.hr


transition countries) have become more significant. For transition countries, these problems are more serious. For example, Kapopoulos and Lazereton (2011) analyse fiscal policy stance and debt sustainability in South-Eastern European countries with the outbreak of GFC in 2008-2009, indicating the problem of growing budget deficits (and public debt).

As a small transition country, B\&H is facing similar problems. Hence, in this paper we use a survey in order to establish whether there is a (dis)content with the current tax policy in $\mathrm{B} \& \mathrm{H}$ and if there is room for improvement. A questionnaire-based survey was conducted in two B\&H entities with the aim of determining public and expert attitudes and opinions towards tax reforms in a small, war-torn transition country - B\&H. Similar opinion-based surveys regarding tax reforms have already been conducted in the USA in three rounds in 1934, 1994, and 2013 (Slemrod 1995, Lim, Slemrod and Wilking 2013, DeGroat 2013) amongst US National Tax Association (NTA) members. Thus, in the US, comparisons to prior surveys or possible shifts in attitudes and opinions have been determined and analysed. In other countries in the world, opinion surveys have only recently become a useful tool in taxation research. Šimović, Blažić and Štambuk (2014, p. 409) provide an overview of general and specific papers based on tax policy based on opinion surveys worldwide. In transition countries and countries in the region, tax-related opinion surveys have been rarely applied. Šimović, Blažić and Štambuk (2013, 2014) present the results of a related tax policy expert opinion survey conducted in Croatia based upon the US survey. Similarly, Klun (2014) does the same for the case of Slovenia. These are the first surveys of this type conducted in the countries in the region. Hence, their significance is even greater, especially bearing in mind that the results from surveys in all three countries will be compared in the future. Therefore, in this paper, we will analyse results from a survey conducted in a B\&H entity, namely the FB\&H, in terms of the economic values and views regarding the tax system of $\mathrm{B} \& \mathrm{H}$. Moreover, summarised results from a similar survey (Antić 2014) conducted in another B\&H entity, namely the Republika Srpska (hereafter: RS), will be presented and briefly compared to the FB\&H results.

Part two of the paper provides a brief summary of tax reforms in B\&H since its independence. The third part defines the methodology and compares results from an analysis regarding status and perspectives of tax reforms in two B\&H entities, FB\&H and RS. The final part focuses on a survey conducted in FB\&H and provides suggestions and recommendations.

\section{TAX REFORMS IN B\&H}

Since the fall of Yugoslavia and Bosnian independence in 1992, B\&H has gone through a difficult and turbulent period. Therefore, unlike any other transition country, it has entered the transition process in a completely war-torn state, since the war in B\&H lasted from 1992 until 1995. During the war, B\&H suffered tremendous human losses and material destruction in terms of ruined infrastructure (e.g. GDP fell by 80 per cent in 1992 compared to 1991, Hadžiahmetović 2005). However, the difficulties for B\&H did not end there. With the end of the war, which was marked by the undersigning of the General Framework Agreement for Peace in Bosnia and Herzegovina, or, more commonly, the Dayton Agreement in 1995, B\&H found itself'stranded' by [through (international) political alchemy] a complicated state organisation unlike any other country in the world [an symmetric (con) federation]. Additionally, such state organisation has no basis either in the historical development of B\&H, nor in any economic logic, but only in the war-painted front lines and the materialised brutal consequences of the war (Kreso and Lazović-Pita 2013).

Hence, with its current ethnic tensions and divided markets, B\&H is presently organised as a two-entity state, with one self-governing administrative unit under the sovereignty of $\mathrm{B} \& \mathrm{H}$. These are the aforementioned entities RS, FB\&H, and the Brčko District (hereafter: BD) respectively. Kreso (2005) presents the current constitutional structure of B\&H. The RS Entity consists of the entity level and municipalities, whereas FB\&H has three levels of government (both excluding cities): the FB\&H entity level, ten cantons and municipalities. BD will not be analysed due to the scope of the paper. Under such circumstances, fiscal policy in $B \& H$ is organised in a similar way to fiscally decentralised countries. However, the possible benefits of fiscal decentralisation in B\&H cannot be determined, primarily due to overlapping authorities. This mainly relates to the number of fiscal institutions without clear (legal) competence. In fact, in $B \& H$, there are fourteen Ministries of Finance (B\&H, FB\&H, RS, BD and ten cantonal); so, together with tax administration under their jurisdictions, this cumbersome public administration causes inefficiency and tax evasion measured by cumulated (and mostly unrecoverable) tax arrears (Indirect Tax Authority 2014, Tax Administration of FB\&H 2014, Tax Administration of RS 2014).

$\mathrm{B} \& \mathrm{H}$ entered the transition process with a tax policy similar to that of Yugoslavia. Tax reforms in RS had begun during the war in B\&H, i.e. in 1992, but were changed very often without a clear aim. In FB\&H, tax reforms began in 1996 and were mostly 
small modifications of the former Yugoslav tax system. Unfortunately, the Dayton Agreement, as the B\&H's Constitution, did not provide any formal grounds in terms of organisation of fiscal policy, unlike monetary policy (under Currency Board Arrangement). Article 3 of the Dayton Agreement only mentioned the regulation of the customs policy under B\&H's competence. Indirect taxes, direct taxes and social security contributions (hereafter: SSC) were under the entity's supervision at the time. Under such circumstances, there were no unified strategies in terms of reforming the current situation in public finances. The reforms that did happen resulted from the efforts of the international community in $B \& H$, namely the Office of the High Representative (hereafter: OHR) and international financial institutions such as the IMF and the World Bank.

Thus, indirect taxes did go through a comprehensive reform under OHR decisions ${ }^{2}$ in 2003, and indirect taxes are currently under the Indirect Tax Authority's (hereafter: ITA) jurisdiction. This means that customs, the value added tax (hereafter: VAT), and excise duties are unified at the level of B\&H. Unification and centralisation of authorities brought numerous benefits, especially in terms of greater indirect tax revenues and more fiscal discipline. Since the replacement of the retail sales tax and the introduction of a broad-basedsingle VAT at the rate of 17 per cent, the ITA has been collecting all indirect tax revenues, which have had an upward trend (except in 2009 compared to 2008 due to the GFC, B\&H Directorate for Economic Planning 2012).

In the field of direct taxes, reforms have been scarce and mostly adopted ad hoc. Some reforms have not been undertaken yet (e.g. SSC). Together with SSC, direct taxes are under the entities' jurisdiction, which causes distortions in terms of the income source and residency principles. Additionally, distortions are present in terms of the number of tax controls, overlapping authorities and, in turn, the availability of public goods (i.e. health, education, etc.). Figure 1 shows current the fiscal structure of B\&H in terms of the legal jurisdiction of each level of government. Figure 2 summarises the main legal changes since 1996 in $\mathrm{B} \& \mathrm{H}$, as well as the legal competence of each level of government within $\mathrm{B} \& \mathrm{H}$. Due to numerous legal changes that occurred at different times, we will divide the process of B\&H tax reforms into two periods: 1995-2006, and since 2006. 2006 was chosen as a benchmark year due to the fact that, in that year, the retail sales tax was replaced with the VAT. This was the biggest tax reform in $\mathrm{B} \& \mathrm{H}$ since its independence and was adopted primarily as a decision of the OHR.

The Decision was adopted in 2003, but it took three years for the entire process to become operational with the introduction of VAT. Moreover, due to the complicated tax system in B\&H, Figure 2 only shows the main legal changes in the main tax types (i.e. customs, excise duties, sales tax - VAT, PIT, CIT, and SSC) since 1996 as changes in tax rates. Changes in tax base, allowances and deductions within each tax type are not considered (see below).

Figure 2 shows an array of legal changes in B\&H. This interpretation relates solely to changes in statutory tax rates without going into details regarding changes in the tax base, allowances, deductions, or the treatment of specific groups of tax payers. If we could highlight two important reforms that occurred since 1996, they would be the replacement of Retail Sales Tax with the VAT in 2006 and the centralisation of indirect taxes (namely, customs and excise duties) at the level of $\mathrm{B} \& \mathrm{H}$. Another important set of reforms occurred in 2008 and 2009 in the RS and FB\&H respectively, and relates to the application of the 'flat tax' model at 10 per cent. Under the 'flat tax' model, we only consider the equalisation of PIT and CIT rates. Moreover, other important taxes such as property taxes, additional taxes on high income earning individuals, etc., were not considered. Figure 2 also shows the differences in the responsibilities of the state $(B \& H)$, entities and other sub-central levels of governments and funds. Again, we will not go into detail regarding

Figure 1: Fiscal Structures of B\&H

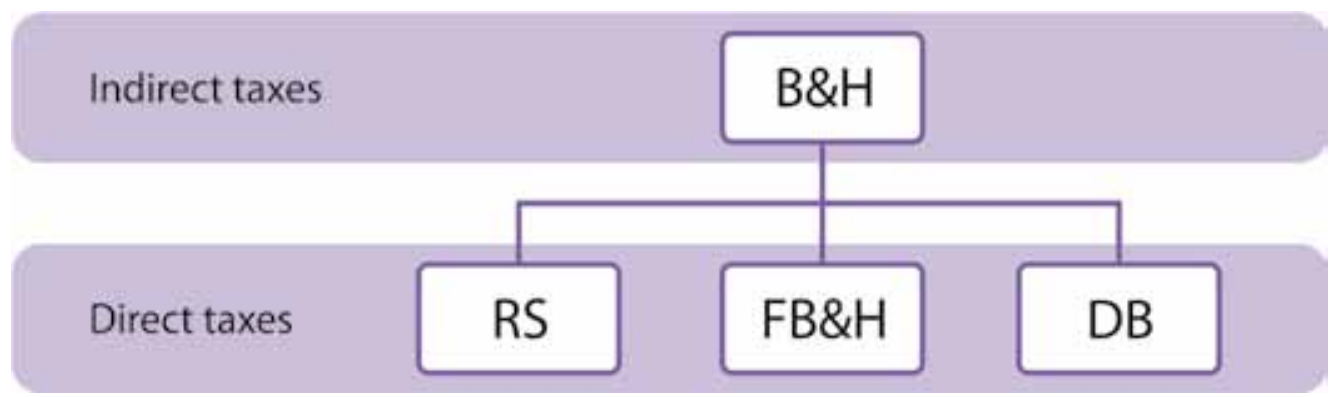

Source: Autors' interpretation. 
Figure 2: Overview of the Main Tax Reforms in B\&H
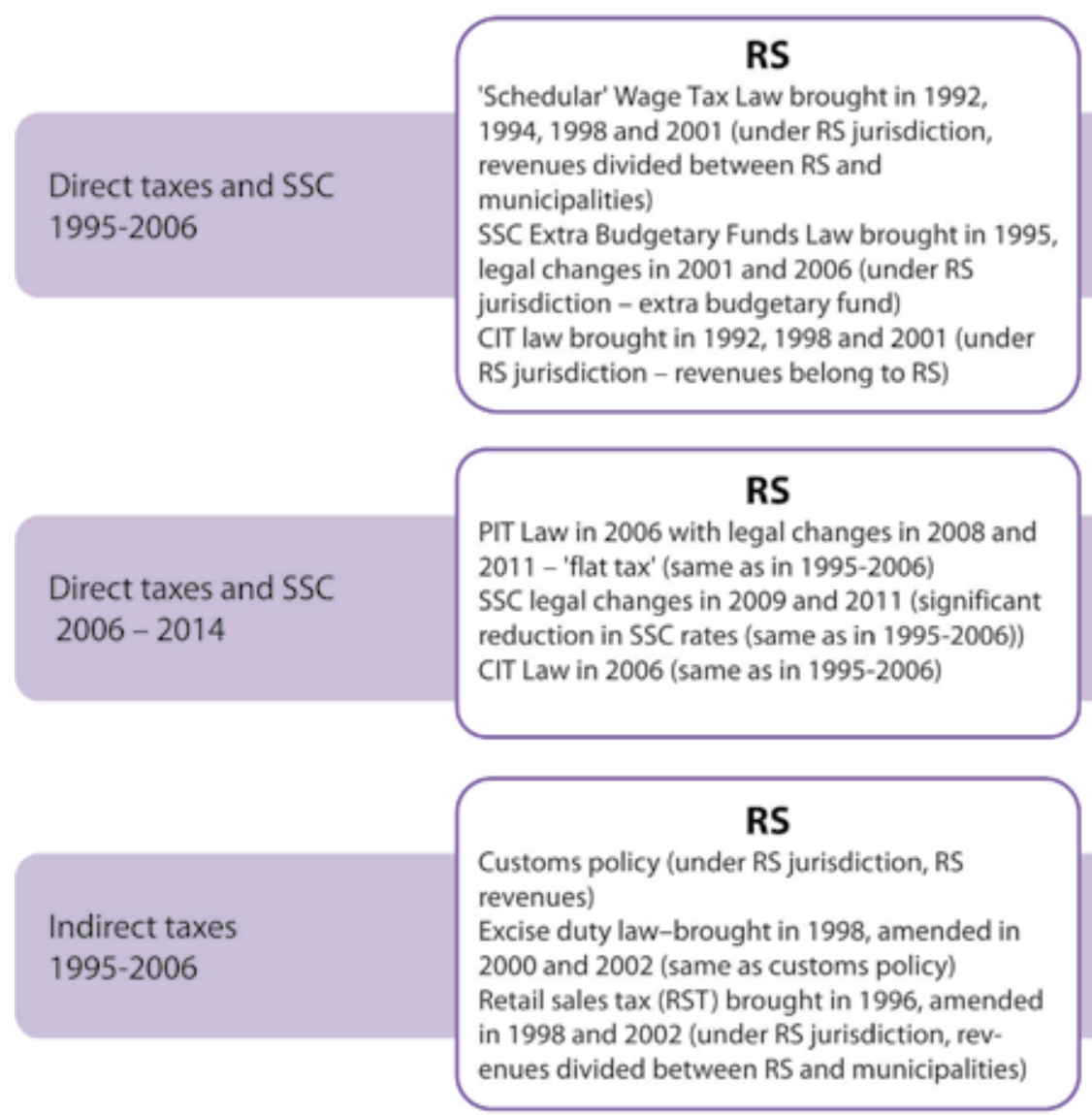

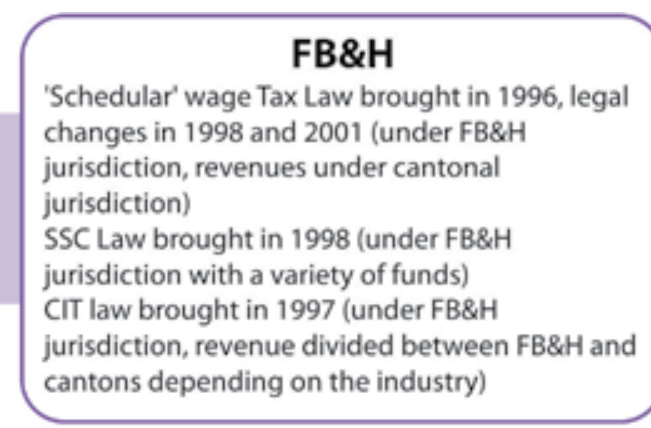

\section{FB\&H}

PIT Law in 2009 - 'flat tax' (under FB\&H jurisdiction, revenues divided between cantons and municipalities)

SSC legal changes in 2009 (reduction in SSC rates, same as in 1995-2006)

CIT Law in 2007 (same as in 1995-2006)

\begin{tabular}{l}
\multicolumn{1}{c|}{ FB\&H } \\
Customs policy (under FB\&H jurisdiction, FB\&H \\
revenues) \\
Excise duty law- brought in 1995, amended in \\
1999 (under FB\&H jurisdiction, collected at \\
cantonal level) \\
Retail sales tax (RST) brought in 1995, amended \\
in 2000 and 2002 (same as excise duties)
\end{tabular}

Indirect taxes

2006-2014

\section{ITA at the level of B\&H}

Customs policy, excise duties and VAT (since 2006) under ITA authority (revenues collected under ITA authority, revenues divided between B\&H, FB\&H, RS and BD)

N.B. information in brackets relates to allotment of revenues between levels of government

Source: Autors' interpretation.

the allocation of revenues between levels of government. We will only note that with the establishment of ITA, financing at the state level of B\&H improved significantly (Kreso 2005). Under such circumstances, conducting a US-type survey in B\&H is a challenging task. Moreover, in almost twenty years of transition process, none of $\mathrm{B} \& \mathrm{H}$ tax reforms were adopted as a result of economic or fiscal reasons in terms of the satisfaction of tax principles. The tax reforms were mainly a result of the aforementioned pressures from the international community; therefore, unlike in developed countries, reforms in B\&H were mostly adopted ad hoc and without quantitative justifications in the decision making process. This is most visible in the VAT introduction at a rate of 17 per cent or the FB\&H PIT reform in 2009 with the introduction of the 10 per cent 'flat tax'. The PIT draft law in FB\&H had suggested two PIT rates of 10 and 15 per cent above a certain threshold, but this was not implemented. Therefore, tax reforms in $\mathrm{B} \& \mathrm{H}$ are a combination of international suggestions and political decisions within $\mathrm{B} \& \mathrm{H}$ rather than thorough economic analysis. Hence, this fact, together with a long and inefficient transition process led by slow and unfinished privatisation, has most certainly affected the opinions and attitudes of all of the target groups covered by the survey.

\section{SURVEY METHODOLOGY}

Expert surveys of this type were first conducted in the USA (Lim, Slemrod and Wilking 2013). In the countries of this region, a similar survey was conducted in Croatia (Šimović, Blažić and Štambuk 2014) and Slovenia (Klun 2014). If we compare the US and Croatian surveys, the US survey consisted of 100 yes/ 
no/don't know statements (Lim, Slemrod and Wilking 2013), and the Croatian survey consisted of 92 statements graded on a five- point Likert scale. Due to the peculiarities of the tax system of each country, the Croatian survey only had about a 20 per cent resemblance to the US survey (Šimović, Blažić and Štambuk 2014). However, the most important statements regarding economic and tax models are the same in both surveys.

Due to the specifics of the B\&H constitution, especially in direct taxes, B\&H's questionnaire was adapted to B\&H's case. Hence, unlike the US and Croatian cases, a questionnaire was separately conducted in FB\&H and RS, and each consisted of 64 and 61 statements respectively. 35 statements related to indirect taxes, and general economic and tax models were the same in both questionnaires. The differences in the number of statements mostly related to statements in the area of property taxes, deductions/exclusions in the area of PIT and the authority of sub-central levels of government in FB\&H - Cantons. However, since the main statements in terms of economic models are the same in both questionnaires, comparison is possible. In both entities, the survey was conducted in the spring and summer of 2014 and, similarly to the Croatian case, a Likert scale was used. Respondents in both entities also provided their main demographic information such as their age, occupation and education. In accordance with the US and the Croatian surveys, respondents were divided into three groups: academics, professionals from the private sector, and the government sector, namely employees of the Ministries of Finance and tax administrations. Before going into details regarding each group, it has to be noted that, although the RS questionnaire was conducted in the same manner as the FB\&H case, the RS results include a very limited number of respondents (only 28 in total). The results from the RS survey are summarised in Antić (2014). Due to the low level of responses in the $R S$, if we added the RS's answers to FB\&H's case, they would be lost in the total number of respondents in the FB\&H (195 responses). Hence, we will only briefly analyse the conclusions of RS respondents and compare them to those of the FB\&H. Therefore, the focus will be on responses from the FB\&H.

The survey was conducted in three main groups. The academics were contacted using e-mail addresses obtained from official universities' websites across the $F B \& H$, and by post. It has to be noted that academics in the FB\&H mostly teach at more than one university, including private universities. In academia, the questionnaire was sent to 87 addresses. The private sector was interviewed by email solely. Since the FB\&H does not legally recognise tax advisory/consultants, this group included employees of international audit and tax advisory companies (i.e. the Big Four employees), domestic audit companies, and most frequently chartered accountants and auditors employed in the financial sector (banks, leasing companies, etc.). The headquarters of such financial institutions are mostly located in the FB\&H. However, what seems to be the problem in the FB\&H is the fact that due to the unregulated tax advisory sector (missing Law on Tax Consultancy/Advisory) individuals from different industries tend to engage in activities for which they are not formally authorised. The only group of professionals that were interviewed and do practically engage in tax advisory/consultancy are those employed in international tax advisory companies and, to some extent, in domestic tax advisory companies. The questionnaire was sent via email to 80 professionals. The government sector was also interviewed, mostly by email and post. When the interview was conducted, the FB\&H government and FB\&H Ministry of Finance faced a challenging period (i.e. violent protests and riots in February 2014, dismissal of the Federal Minister of Finance, etc.), and therefore, conducting a survey under such circumstances was very difficult. However, the survey was forwarded to the managing director of the Tax Administration of FB\&H and was conducted among tax inspectors, employees inside the Central Office and the heads and deputies of cantonal tax offices in FB\&H. Some were sent via email and some via post. The total number of potential respondents is therefore unknown, but the response in this group is considerable, since 110 surveys were filled out. The employees of the FB\&H's Ministry of Finance, as well as the ITA, were also interviewed, but they make up only 14 per cent of all of the government officials that were interviewed. Thus, in total, 195 individuals responded to the survey in FB\&H. In the RS, out of the 28 respondents, the most significant part was taken up by the government sector. Table 1 summarises the respondent structure for the FB\&H.

Table 1: Respondent structure in the FB\&H

\begin{tabular}{|l|r|r|}
\hline \multirow{2}{*}{ Groups } & \multicolumn{2}{c|}{ FB\&H* } \\
\cline { 2 - 3 } & No. & \multicolumn{1}{c|}{$\%$} \\
\hline $\begin{array}{l}\text { The academic community } \\
\text { (universities, institutes) }\end{array}$ & 44 & $22.7 \%$ \\
\hline The government sector & 111 & $57.2 \%$ \\
\hline The private sector & 39 & $20.1 \%$ \\
\hline Total & 194 & $100.0 \%$ \\
\hline
\end{tabular}

* One respondent did not answer this question (195 questionnaires were filled in).

Source: Authors. 
Figure 3 summarises the structure of the FB\&H's dataset. Similar to the Croatian case, most of the government sector and academia is taken by tax administration, and those teaching economics, respectively. However, unlike in the Croatian case, where 50 per cent of all private sector respondents were tax advisors, in the FB\&H only 26 per cent of the sample are tax advisors (Šimović, Blažić and Štambuk 2013). In FB\&H, the interviewed tax advisors were all employed in international and domestic tax consultancies. Thus, the majority of those interviewed in the private sector in FB\&H were chartered accountants and auditors working in the financial sector in FB\&H and dealing with taxes to some extent.

Figure 4 interprets the educational structure of the dataset for the FB\&H. All experts have at least a bachelor's degree ${ }^{3}$. In the FB\&H, the reason for this lies in the fact that the majority of the dataset is taken up by those employed in the government sector/tax administration. Academia and the private sector mostly have Ph.D. and master's degrees, respectively. In the FB\&H, 50.7 per cent of the dataset were younger than 44 years of age, the average age in the private sector was 35 years, in academia 41, and in the government sector 49 years of age. The mode value in the FB\&H is 57 years of age.

In order to conduct a comparative analysis in relation to the US or the Croatian survey, we will have to adopt a similar methodology. In the US and the Croatian surveys a reasonable benchmark of at least 61 per cent of yes/no answers (without neutral response) was considered a degree of consensus (Lim, Slemrod and Wilking 2013). Given that the FB\&H case, similarly to the Croatian case, uses the Likert scale, answers were
Figure 3: The Structure of the Dataset in the FB\&H by sectors

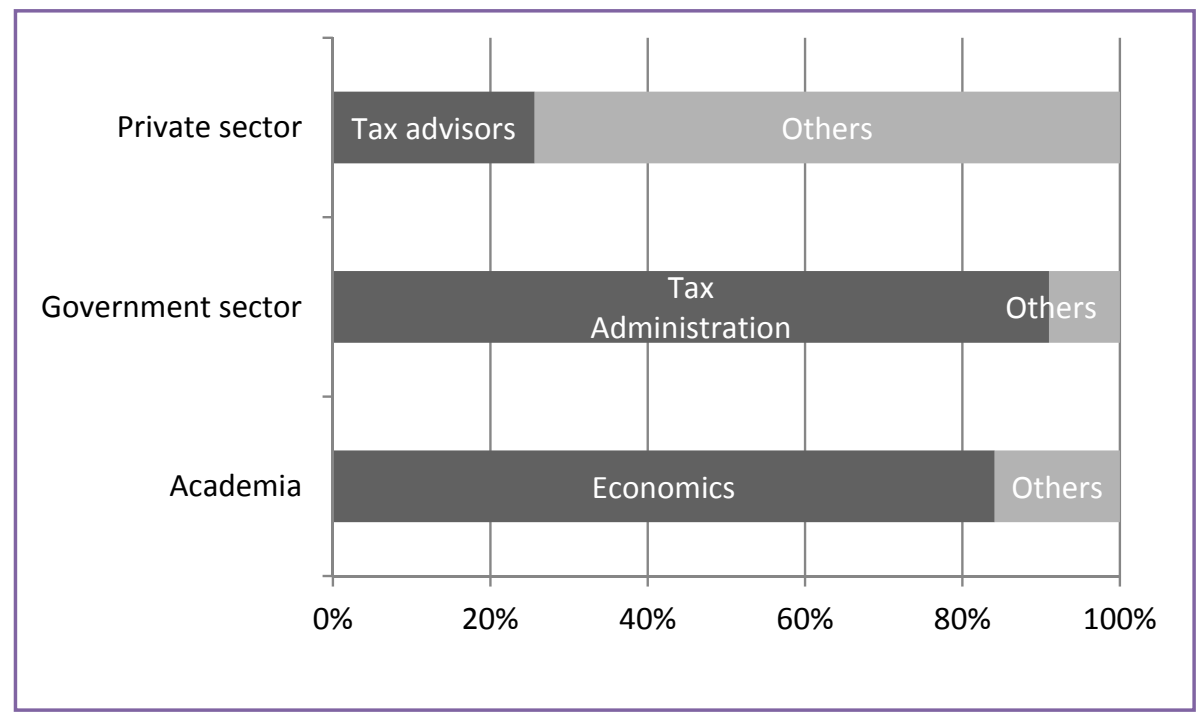

Source: Authors.

Figure 4: Educational structure of respondents in the FB\&H

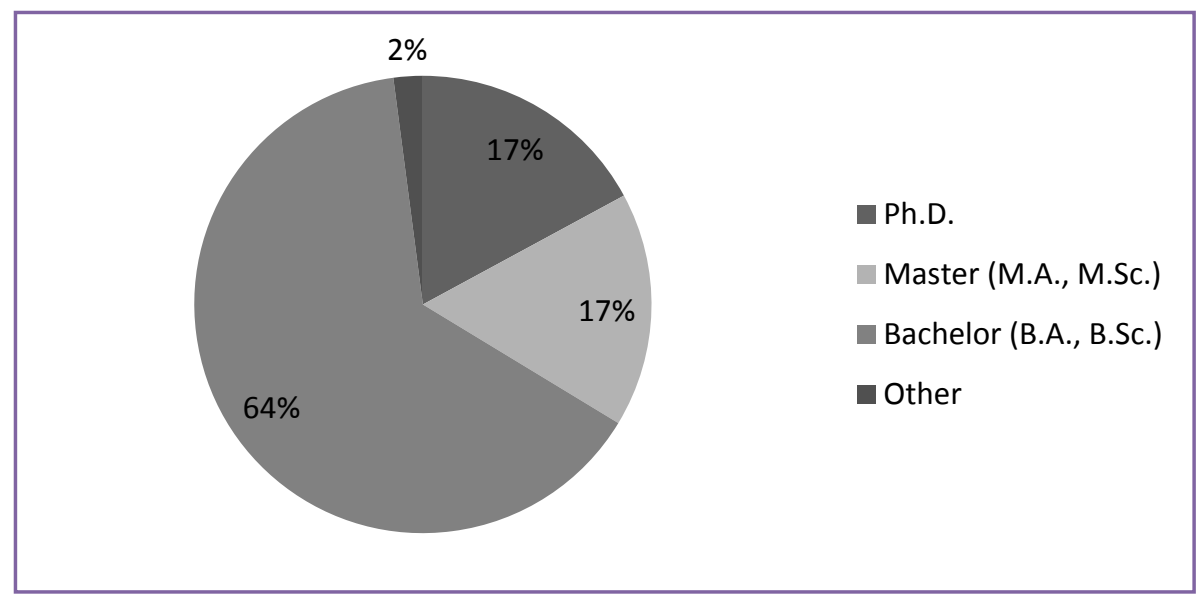

Source: Authors.

Table 2: Degree of Consensus (Number of Statements, without Neutral Response)

\begin{tabular}{|l|c|c|c|c|}
\hline Degree of consensus & Total & Academic & Government & Private \\
\hline Total 61-74\% & 24 & 21 & 23 & 16 \\
\hline Total $75-100 \%$ & 33 & 35 & 31 & 39 \\
\hline Total 61-100\% & 57 & 56 & 54 & 55 \\
\hline Total 61-100\% (in \%) & 89.1 & 87.5 & 84.4 & 85.9 \\
\hline
\end{tabular}

Source: Authors. 
summarised in a similar manner (without neutral answers). Table 2 summarises responses to the FB\&H survey with a degree of consensus of at least 61 per cent and a more certain degree of consensus of 75 per cent, respectively.

Under the degree of consensus of 61 per cent in the US, 84 statements (out of 100) fulfilled this benchmark in the 2013 survey (Lim, Slemrod and Wilking 2013). In the Croatian case, 64 (out of 92 statements) fulfilled this criterion (Šimović, Blažić and Štambuk 2014). In the FB\&H, 57 (out of 64 statements) reached the given degree of consensus, which is almost 90 per cent. A high level of consensus is definitely a good indicator, but does not necessarily indicate a consistent tax policy. Most (if not all) legal changes in the FB\&H were far from serious tax reforms and were usually initiated and conducted by pressures from the international community in (F)B\&H. This is most certainly true for all indirect taxes, slow and uncertain reforms in the field of direct taxes, and no reforms in the area of SSC. In order to provide an overall analysis of responses in the following part, we will interpret the results from the Likert scale ( 1 to 5 ) as follows: answers 1 and 2 will be summarised as 'I disagree', answer 3 is 'neutral', and answers 4 and 5 as'l agree ${ }^{\prime 4}$.

\section{TAX ISSUES AND THE ECONOMIC MODEL IN THE FB\&H WITH COMPARISONS TO THE RS}

In comparison to the US and Croatian surveys, which had 100 and 92 statements respectively, the FB\&H survey only included 64 statements. The reason for this limited number of statements in the FB\&H survey (and that of the RS) mostly relates to the fact that some statements were not applicable in the case of B\&H (both entities). In this part of the paper, we will only compare the overall results among a limited number of statements in the FB\&H and RS, and will try to include the level of consensus. Statements/ questions were selected based on their significance in overall fiscal policy in terms of whether they were popular policy options, or whether there were significant differences in attitudes among the entities. Thus, in both entities, the questionnaires were divided into four groups.

The first part concerned statements regarding indirect taxes at the level of $B \& H$, the second part related to general tax issues and economic models, the third part concerned property tax, and the final part dealt with direct taxes, namely PIT and CIT. The first and the second parts are identical in both surveys.

Table 3 summarises most distinct responses as yes/ no/neutral responses to the questionnaire among the two B\&H entities. Responses were virtually the same in both entities to statements regarding the treatment of excise duties, so they are not shown in Table 3. However, disagreement among entities was visible in responses dealing with the VAT. A statement regarding the introduction of a reduced VAT rate in the FB\&H was responded positively by 72 per cent of respondents. Response to this statement in RS was divided in half between those who agreed and disagreed (Antić 2014). More specifically, in the FB\&H survey, those coming from the government sector mostly agreed with this statement (72 per cent) whereas in the RS, the government sector mostly disagreed. The overall result in the RS was divided in half amongst those who agreed and disagreed (i.e. exactly 50 per cent, Antic 2014). The reason perhaps lies in the fact that most of those interviewed in the RS come from ITA, and are therefore aware of the additional complexity of the introduction of a reduced VAT rate (since the ITA is completely in charge of indirect taxes), whereas in the $\mathrm{FB} \& \mathrm{H}$, those coming from the government sector are mostly in charge of direct taxes, so they mostly agreed with this statement.

In the second part, which regarded general tax issues and economic models, there were significant differences in opinion. One particular statement is important and relates to the efficiency-equity trade-off. In the RS case, respondents were divided and could not give preference to either the efficiency or equity principle (Antić 2014). In the FB\&H, the preference was given to the equity principle over the efficiency principle (62 per cent). Responses regarding an increase in

Table 3: Summary of Expert Attitudes Regarding Indirect Taxes in the RS and FB\&H, in \%

\begin{tabular}{|c|c|c|c|c|c|c|}
\hline \multirow[b]{2}{*}{ Statement } & \multicolumn{3}{|c|}{ RS } & \multicolumn{3}{|c|}{ FB\&H } \\
\hline & No & Neutral & Yes & No & Neutral & Yes \\
\hline Q01. B\&H should introduce reduced VAT rate. & 50 & 0 & 50 & 26 & 2 & 72 \\
\hline Q02. Standard VAT rate should be increased. & 78 & 12 & 10 & 72 & 6 & 22 \\
\hline
\end{tabular}

N.B. Data for RS are estimated based upon Antić, 2014.

Source: Autors' calculation. 
tax penalties and satisfaction of the compliance principle in creating tax policy were positively responded to in FB\&H, with 67 per cent agreeing. In the RS, more than 80 per cent agreed. The lower rate of responses in the $\mathrm{FB} \& \mathrm{H}$ to this question is a result of responses from the government sector. In the government sector in the $\mathrm{FB} \& \mathrm{H}$, which is in charge of the administration of tax penalties, only 60 per cent agreed. We can only assume that the government sector in the FB\&H faces different problems, such as establishing tax frauds, so they do not think that penalties for tax evasion/frauds should increase. In both the RS and FB\&H, the remaining economic model issues are mostly responded to similarly. All respondents in the FB\&H and RS feel that the SSC should not be increased. Although SSC rates have had a falling tendency in both entities, they significantly differ across the two entities in amount. In the FB\&H, they amount to 41.5 per cent and are paid both by employer and employee, whereas in the RS they amount to 33 per cent and are all paid by the employer. Additionally, in the FB\&H, all feel that the SSC paid by employee and employer should be consolidated into one payment (similar to the RS practice). Furthermore, all respondents in the FB\&H and RS agreed on issues such as the lowering of the tax burden relative to GDP, reduction of public revenues and expenditures relative to GDP, and changes in the tax structure. Moreover, respondents in the FB\&H feel that lower marginal income tax rates reduce leisure and increase work effort, that non-taxation of interest and financial capital gains encourages saving and investment, respectively, and that government tax relief and

Table 4: Summary of Expert Attitudes Regarding General Tax issues and Economic Models in the RS and FB\&H, in \%

\begin{tabular}{|c|c|c|c|c|c|c|}
\hline \multirow[b]{2}{*}{ Statement } & \multicolumn{3}{|c|}{ RS } & \multicolumn{3}{|c|}{$\mathrm{FB} \& \mathrm{H}$} \\
\hline & No & Neutral & Yes & No & Neutral & Yes \\
\hline $\begin{array}{l}\text { Q19. Social security contributions should be increased at all levels } \\
\text { (Pension, Health, Unemployment). }\end{array}$ & 100 & 0 & 0 & 86 & 5 & 9 \\
\hline $\begin{array}{l}\text { Q22. The entire tax burden (the level of taxes relative to GDP) should } \\
\text { be reduced. }\end{array}$ & 15 & 18 & 67 & 16 & 18 & 66 \\
\hline $\begin{array}{l}\text { Q24. The entire level of public revenues (and public expenditures) } \\
\text { relative to GDP should be lowered. }\end{array}$ & 15 & 18 & 67 & 13 & 23 & 63 \\
\hline Q25. The tax structure should be changed. & 5 & 28 & 67 & 7 & 16 & 77 \\
\hline $\begin{array}{l}\text { Q26. The tax burden should be shifted from personal and corporate } \\
\text { income to consumption. }\end{array}$ & 45 & 15 & 40 & 39 & 17 & 44 \\
\hline $\begin{array}{l}\text { Q27. The tax burden should be shifted from personal and corporate } \\
\text { income to property. }\end{array}$ & 32 & 18 & 50 & 28 & 21 & 51 \\
\hline $\begin{array}{l}\text { Q28. Lower marginal income tax rates reduce leisure and increase } \\
\text { work effort. }\end{array}$ & 23 & 20 & 57 & 24 & 24 & 52 \\
\hline Q29. Non-taxation of interest encourages saving. & 11 & 10 & 79 & 20 & 12 & 68 \\
\hline $\begin{array}{l}\text { Q30. Non-taxation of financial capital gains encourages investment } \\
\text { and promotes economic growth. }\end{array}$ & 11 & 10 & 79 & 20 & 18 & 62 \\
\hline $\begin{array}{l}\text { Q31. Different government tax reductions (reliefs, incentives) } \\
\text { promote economic growth. }\end{array}$ & 13 & 8 & 79 & 14 & 12 & 74 \\
\hline Q32. VAT is regressive. & 39 & 18 & 43 & 44 & 22 & 34 \\
\hline $\begin{array}{l}\text { Q33. Administrative and compliance costs of taxation should play a } \\
\text { significant role in creating tax policy (these costs should be reduced } \\
\text { by making the tax system significantly simpler). }\end{array}$ & 19 & 3 & 78 & 8 & 9 & 83 \\
\hline $\begin{array}{l}\text { Q34. The equity principle should have priority over the efficiency } \\
\text { principle in creating tax policy. }\end{array}$ & 33 & 33 & 34 & 19 & 19 & 62 \\
\hline Q35. Penalties for tax evasion should be increased. & 22 & 8 & 70 & 25 & 7 & 67 \\
\hline
\end{tabular}

N.B. Differences exist due to rounding errors or omitted responses.

Source: Autors' calculation and Antić (2014). 
incentives promote economic growth. Additionally, only 43 per cent in the RS and 34 per cent in the FB\&H consider the current single-rate VAT to be regressive. Within this group of statements, the most interesting statements related to 'incidence' statements were undecided responses from both entities. In the statement regarding a shift from income to consumption, respondents in the FB\&H and RS reached similar levels of responses, with 40 per cent of respondents agreeing with this statement. Alternatively, responses regarding a shift from income to property reached 50 per cent of positive answers in both entities. Table 4 summarises the responses as yes/no/neutral answers for general tax issues and economic models.

The third part of the survey included property taxes. Since this part of tax policy is under the entities' supervision, most differences between the statements are in this (and final) part of the survey. The statement that is positively answered in both entities is related to the fact that property is a necessary additional indicator of the ability to pay besides income. Unlike the RS case, which did not have a specific set of statements, in the FB\&H respondents agreed that the FB\&H needs property tax reform and that ten cantonal laws should be consolidated into one. Furthermore, respondents in both entities answered positively to the statement regarding real estate tax being local tax in terms of revenues. The final part of the survey is related to statements about income taxes, namely personal and corporate income tax (PIT and CIT). Since these types of taxes, together with property taxes are under entities' legal supervision, there were differences in this part of the survey among entities. The most important statement regarding the introduction of progressive PIT in the FB\&H and RS was positively answered. Additionally, respondents in both the FB\&H and RS disagree with the possible increase of the 'flat tax' rate. Responses regarding introduction of progressive PIT in the FB\&H are expected, but not in the RS. If we link the response to this statement to the efficiency-equity trade-off, we will see that the respondents in the FB\&H are consistent, whereas in the RS that is not the case. In the FB\&H, respondents gave priority to the equity principle (vertical equity) over efficiency, since the redistributive function of the state is, at least in theory, best satisfied through progressive PIT (Musgrave and Musgrave 1993). In the RS, 57 per cent of those primarily coming from the government sector were in favour of progressive PIT. The reason for favouring progressive PIT in the RS might perhaps lie in the fact that the government sector in RS, regardless of the PIT rate (flat or progressive), always pays out the same net wage to its employees, i.e. if and when legal changes in the tax rate occur (or the tax base in terms of standard and non-standard allowances) the government sector in the RS always corrects the gross wage, so that the net wage paid to employees would not be changed. In the FB\&H, all responses regarding standard allowances and deductions are mostly unanimous and are similar to the RS responses (where comparable). Moreover, in the FB\&H, the majority feel that financial capital gains and dividends should be taxed within PIT. This implies that all favour comprehensive a SHS definition of income, rather than an expenditure-based one. Additionally, in the FB\&H, only slightly more than 50 per cent think that dividends should be given preferential treatment to other sources of income in terms of lower tax rates. These responses in the FB\&H are particularly interesting, bearing in mind that dividends under 'flat tax' are currently not subject to tax. In the RS, on the other hand, under 10 per cent of 'flat tax' dividends are subject to taxation. In the $\mathrm{RS}$, opinions regarding taxation of dividends are divided between the private (disagree) and government (agree) sectors (Antić 2014), but the majority agreed with preferential treatment of dividends compared to other sources of income.

Fringe benefits should continue to be exempt from taxation of income in the FB\&H, and a cantonal/ municipal surtax should not be introduced. The positive answer regarding non-taxation of fringe benefits from the FB\&H's government sector is very peculiar, especially bearing in mind that non-taxation of fringe benefits narrows the tax base and can act in a stimulating way in terms of underreporting or 'envelope salaries'. Again, a small, war-torn transition country such as B\&H with divided markets faces serious challenges regarding the high levels of the shadow economy (Schneider 2012). Moreover, the opinion regarding non-taxation of fringe benefits in the case of the FB\&H is very concerning since fringe benefits take on average 40 per cent of the average monthly net wage, whereas in OECD countries they take as little as 1-2 per cent (OECD 2014). Regarding CIT, respondents in the FB\&H and the RS think that CIT rates should not be increased (similar to answers regarding an increase in PIT rates). Similar answers were given in other areas of $\mathrm{CIT}$ in both entities. Table 5 summarises the aforementioned main results in the FB\&H's and RS' statements in the third and final part of the survey grouping answers as yes/no/neutral. 
Table 5: Summary of Expert Attitudes Regarding Direct Taxes in the RS and FB\&H, in \%

\begin{tabular}{|c|c|c|c|c|c|c|}
\hline \multirow[b]{2}{*}{ Statement } & \multicolumn{3}{|c|}{ RS } & \multicolumn{3}{|c|}{$\mathrm{FB} \& \mathrm{H}$} \\
\hline & No & Neutral & Yes & No & Neutral & Yes \\
\hline $\begin{array}{l}\text { Q43_Property is a necessary additional indicator of ability to pay } \\
\text { besides income. }\end{array}$ & 6 & 13 & 81 & 8 & 10 & 82 \\
\hline Q46_Progressive income tax should be introduced. & 28 & 15 & 57 & 29 & 5 & 66 \\
\hline $\begin{array}{l}\text { Q47_Current personal income tax rate of } 10 \text { per cent should be } \\
\text { increased. }\end{array}$ & 79 & 21 & 0 & 74 & 13 & 14 \\
\hline $\begin{array}{l}\text { Q48_Personal allowances in personal income tax should be re- } \\
\text { introduced/abolished (RS and FB\&H respectively). }\end{array}$ & 12 & 10 & 78 & 77 & 6 & 17 \\
\hline Q49_Family allowances should be abolished. & 94 & 3 & 3 & 82 & 5 & 12 \\
\hline $\begin{array}{l}\text { Q50_Tax deductions/allowances for health costs should be } \\
\text { introduced/abolished (RS and FB\&H respectively). }\end{array}$ & 9 & 16 & 75 & 71 & 7 & 21 \\
\hline $\begin{array}{l}\text { Q51_Tax deductions/allowances for owner-occupied housing } \\
\text { should be abolished. }\end{array}$ & 72 & 7 & 21 & 67 & 7 & 26 \\
\hline $\begin{array}{l}\text { Q53_Inside PIT, dividends should (not for the RS) } \\
\text { be taxed. }\end{array}$ & 48 & 7 & 45 & 25 & 9 & 66 \\
\hline Q54_Inside PIT, financial capital gains should be taxed. & 27 & 21 & 52 & 23 & 14 & 63 \\
\hline $\begin{array}{l}\text { Q55_Inside PIT, interest on saving and securities should } \\
\text { be taxed. }\end{array}$ & 78 & 2 & 20 & 72 & 8 & 20 \\
\hline $\begin{array}{l}\text { Q56_All sources of income inside PIT should be taxed in the same } \\
\text { way (at statutory rates, without allowing the lower withholding } \\
\text { tax to be the final tax due). }\end{array}$ & 45 & 25 & 30 & 42 & 26 & 32 \\
\hline $\begin{array}{l}\text { Q57_Capital incomes should be taxed at lower rates than labour } \\
\text { incomes. }\end{array}$ & 54 & 23 & 23 & 53 & 19 & 28 \\
\hline $\begin{array}{l}\text { Q58_Dividends should be taxed at lower rates than other incomes } \\
\text { (due to the economic double taxation of dividends). }\end{array}$ & 22 & 14 & 64 & 34 & 16 & 51 \\
\hline $\begin{array}{l}\text { Q59_Compensation of employees (i.e. fringe benefits) should } \\
\text { continue to be exempt from taxation on income. }\end{array}$ & 26 & 2 & 72 & 17 & 7 & 77 \\
\hline $\begin{array}{l}\text { Q60_Cantonal/municipal surtax should be } \\
\text { introduced. }\end{array}$ & 72 & 28 & 0 & 60 & 22 & 18 \\
\hline Q61_Corporate income tax rate should be increased. & 65 & 10 & 25 & 62 & 9 & 29 \\
\hline
\end{tabular}

Source: Autors' calculation and Antić (2014).

\section{BINOMIAL PROBIT REGRESSION RESULTS FOR ECONOMIC VALUES IN THE FB\&H}

Similar to the US (Lim, Slemrod and Wilking 2013) and Croatian surveys (Šimović, Blažić and Štambuk 2014), we have developed a model regarding responses to the most important two statements dealing with tax reforms: those are statements 24 and 34 . They were used as predictors (independent variables). Statements 24 and 34 relate to opinions regarding the lowering of the entire level of public revenues and expenditures to GDP and giving preference to the equity aspect over efficiency, respectively. In the Croatian survey, similar statements were used as predictors (the difference is in statement 24, but the inclination is the same in the Croatian survey). Those who answered positively to statement 24 are considered to be more neo-liberal in their economic values, i.e. they are promoting a lesser role of government in the economy. They are more likely to promote base-broadening measures as well as reduction in the top tax rates.

Those who answered positively to statement 34 are in favour of (vertical) equity and could be regarded as more 'classical interventionists' favouring redistributive issues. They should also favour greater government involvement in the economy. Moreover, unlike the former group, this group should be more in favour of a comprehensive $\mathrm{S}-\mathrm{H}-\mathrm{S}$ definition of income. Twenty six regressions were conducted. A binomial probit regression included grouped yes/no answers without neutral answers. The regression includes demographic characteristics (such as age, education, and employment sector) as independent variables, but they are not specifically analysed. The private sector is used as 
a benchmark. Education as a benchmark is classified in two groups: those with and without Ph.D.

Thus, results presented in Table 6 show a few important points regarding general attitudes and specifics in terms of responses.

Those who answered positively to statement Q24 (compared to those who responded negatively 5 ) are, unexpectedly, more likely to answer positively to the statement regarding the introduction of a financial transaction tax. This answer is not expected since this group should favour lesser government intervention, and hence taxation. In responses regarding PIT, those who claim lesser government involvement in the economy are more likely to favour abolishment of tax deductions for health costs in personal income taxation. This could be interpreted as a base-broadening

Table 6: Binomial Probit Regression Results for Economic Values in the FB\&H

\begin{tabular}{|c|c|c|c|}
\hline Question/Statement & Q24a & Q34b & $x^{2} e$ \\
\hline \multirow[b]{2}{*}{ Q01. B\&H should introduce reduced VAT rate. } & 0.222 & 0.484 & 6831 \\
\hline & $(0.369)$ & $(0.327)$ & [0.337] \\
\hline \multirow[b]{2}{*}{ Q02. Standard VAT rate should be increased. } & -0.651 & $-0.767^{* *}$ & 10425 \\
\hline & $(0.424)$ & $(0.389)$ & [0.108] \\
\hline \multirow[b]{2}{*}{ Q13. Excise duties on tobacco and tobacco products should be increased. } & -0.168 & 0.42 & 6037 \\
\hline & $(0.445)$ & $(0.397)$ & [0.419] \\
\hline \multirow{2}{*}{$\begin{array}{l}\text { Q19. Social security contributions should be increased at all levels (Pension, Health, } \\
\text { Unemployment). }\end{array}$} & 0.621 & 0.447 & 491025 \\
\hline & $(0.386)$ & $(0.568)$ & [0] \\
\hline \multirow[b]{2}{*}{ Q20. A financial transaction tax should be introduced. } & $1.182^{* *}$ & $-0.713^{*}$ & 18869 \\
\hline & $(0.533)$ & $(0.416)$ & [0.004] \\
\hline \multirow[b]{2}{*}{ Q21. A financial activities tax should be introduced. } & 0.176 & $1.341^{* * *}$ & 21.32 \\
\hline & $(0.391)$ & $(0.413)$ & [0.002] \\
\hline \multirow{2}{*}{$\begin{array}{l}\text { Q23. General government should be financed less from taxes and more from different } \\
\text { non-tax revenues (with an emphasis on different user charges). }\end{array}$} & $1.424^{* * *}$ & -0.595 & 13315 \\
\hline & $(0.431)$ & $(0.394)$ & [0.038] \\
\hline \multirow{2}{*}{$\begin{array}{l}\text { Q39. Taxation should include other forms of property, too (movable property, financial } \\
\text { property, etc.), i.e. should be a synthetic taxation of property (net wealth tax). }\end{array}$} & 0.348 & -0.431 & 500844 \\
\hline & $(0.453)$ & $(0.406)$ & [0] \\
\hline \multirow[b]{2}{*}{ Q41. Inheritances and gifts should be taxed. } & 0.204 & -0.117 & 8643 \\
\hline & $(0.373)$ & $(0.344)$ & [0.195] \\
\hline \multirow[b]{2}{*}{ Q43. Property is a necessary additional indicator of ability to pay besides income. } & -0.108 & $0.678^{*}$ & 8727 \\
\hline & $(0.595)$ & $(0.402)$ & {$[0.19]$} \\
\hline \multirow[b]{2}{*}{ Q46. FB\&H should introduce progressive income tax. } & 0.214 & 0.112 & 19025 \\
\hline & $(0.386)$ & $(0.34)$ & [0.866] \\
\hline \multirow[b]{2}{*}{ Q47. Current personal income tax rate of 10 per cent should be increased. } & $-0.883^{*}$ & $0.917^{*}$ & 18982 \\
\hline & $(0.486)$ & $(0.534)$ & [0.004] \\
\hline \multirow[b]{2}{*}{ Q48. Personal allowances in personal income tax should be abolished. } & 0.12 & $-0.75^{*}$ & 9613 \\
\hline & $(0.434)$ & $(0.407)$ & [0.142] \\
\hline \multirow[b]{2}{*}{ Q49. Family allowances should be abolished. } & -0.093 & $-0.702^{*}$ & 7129 \\
\hline & $(0.434)$ & $(0.373)$ & [0.309] \\
\hline \multirow[b]{2}{*}{ Q50. Tax deductions/allowances for health costs should be abolished. } & $1.117^{* *}$ & $-0.722^{*}$ & 10044 \\
\hline & $(0.548)$ & $(0.376)$ & [0.123] \\
\hline \multirow[b]{2}{*}{ Q51.Tax deductions/allowances for owner-occupied housing should be abolished. } & 0.511 & -0.517 & 26146 \\
\hline & $(0.455)$ & $(0.348)$ & [0.191] \\
\hline \multirow[b]{2}{*}{ Q53. Inside PIT, dividends should be taxed. } & -0.098 & $-0.71^{*}$ & 6848 \\
\hline & $(0.398)$ & $(0.404)$ & [0.335] \\
\hline \multirow[b]{2}{*}{ Q54. Inside PIT, financial capital gains should be taxed. } & -0.29 & $-0.697^{*}$ & 5332 \\
\hline & $(0.421)$ & $(0.401)$ & {$[0.502]$} \\
\hline
\end{tabular}




\begin{tabular}{|c|c|c|c|}
\hline \multirow[b]{2}{*}{ Q55. Inside PIT, interest on saving and securities should be taxed. } & -0.435 & -0.24 & 42253 \\
\hline & $(0.386)$ & $(0.344)$ & {$[0.33]$} \\
\hline \multirow{2}{*}{$\begin{array}{l}\text { Q56. All sources of income inside PIT should be taxed in the same way (at statutory } \\
\text { rates, without allowing the lower withholding tax to be the final tax due). }\end{array}$} & 0.186 & -0.28 & 9184 \\
\hline & $(0.377)$ & $(0.357)$ & [0.163] \\
\hline \multirow[b]{2}{*}{ Q57. Capital incomes should be taxed at lower rates than labour incomes. } & 0.451 & 0.193 & 9193 \\
\hline & $(0.474)$ & $(0.393)$ & [0.163] \\
\hline \multirow{2}{*}{$\begin{array}{l}\text { Q58. Dividends should be taxed at lower rates than other incomes (due to the eco- } \\
\text { nomic double taxation of dividends). }\end{array}$} & 0.003 & -0.085 & 0.958 \\
\hline & $(0.373)$ & $(0.346)$ & [0.987] \\
\hline \multirow{2}{*}{$\begin{array}{l}\text { Q59. Compensation of employees (i.e. fringe benefits) should continue to be exempt } \\
\text { from taxation on income. }\end{array}$} & 0.112 & 0.186 & 3347 \\
\hline & $(0.422)$ & $(0.359)$ & {$[0.764]$} \\
\hline \multirow[b]{2}{*}{ Q61. Corporate income tax rate should be increased. } & 0.047 & -0.253 & 4057 \\
\hline & $(0.435)$ & $(0.377)$ & [0.669] \\
\hline \multirow{2}{*}{$\begin{array}{l}\text { Q62. Differentiated/reduced corporate income tax rates should be introduced for cer- } \\
\text { tain industries (e.g. agriculture, tourism). }\end{array}$} & -0.229 & -0.072 & 34001 \\
\hline & $(0.427)$ & $(0.348)$ & [0.818] \\
\hline \multirow[b]{2}{*}{ Q64. Reinvested profits should be exempt from taxation. } & 0.255 & 0.17 & 2392 \\
\hline & $(0.448)$ & $(0.422)$ & [0.793] \\
\hline
\end{tabular}

Notes: Robust standard errors are in parenthesis. The $\mathrm{p}$-values of the $\mathrm{x} 2$ are in brackets. Other regressors include indicators of sector of employment, age and education.

${ }^{*} p<0.1 ; * * 0.05 ;{ }^{* * *} p<0.01$

aQ24 - The entire level of public revenues (and public expenditures) relative to GDP should be lowered. bQ34 - The equity principle should have priority over the efficiency principle in creating tax policy.

Source: Authors' calculation.

measure within PIT. This group is more likely to answer negatively to the statement regarding an increase in the current 10 per cent 'flat rate'. This is in line with the laissez faire ideology. Unfortunately, other statements regarding the definition of the tax base were not significant.

Tax experts inclined to a greater role of government (i.e. those who answered positively to statement 34 in comparison to those who answered negatively) are more likely to disagree on a statement regarding an increase in the standard VAT rate. The responses to this statement could be explained as an awareness of tax experts that the current application of single-rate broad-based VAT causes regressivity and in turn distorts equity. However, one must not forget that most tax experts answered negatively to the statement regarding VAT regressivity (although a consensus was not reached on this particular statement). Moreover, experts might also feel that the standard VAT rate has already reached its peak at 17 per cent, even though this is currently the lowest VAT rate in the region. Contrary to expectations, this group is more likely to disagree on the introduction of a financial transactions tax. This could be justified by fragmented and underdeveloped financial markets in (F)B\&H. However, those who favour equity over efficiency are more inclined toward the introduction of a financial activities tax. This could be justified by the fact that the FB\&H financial market is bank-based. Expectedly, this group is more inclined to favour an increase in the current 10 per cent 'flat tax' and consider that property a necessary additional indicator of the ability to pay besides income. Additionally, this group is inclined to answer negatively regarding an abolishment of all allowances (personal, family and owner-occupied housing) which is in line with expectations. However, what is unexpected is the fact that this group is more inclined to be against the taxation of dividends and financial capital gains. Taxation of dividends and financial capital gains (realised) is a crucial parameter in the definition of the comprehensive income under $\mathrm{S}-\mathrm{H}-\mathrm{S}$, which represents satisfaction of the ability-to-pay principle. However, this response among FB\&H experts reflects the current policy of non-taxation of dividends and capital gains which in turn causes income shifting. Thus, the results shown in Table 6 in terms of economic values in the FB\&H are unclear, with numerous unexpected answers indicating two important points: this brief analysis proves the point that tax reforms are adopted ad hoc and under pressure from the international community, and therefore, local tax experts have little knowledge regarding specific tax issues; the second point builds on the first regarding the crucial definition of the tax base in terms of its broadness (or narrowness), especially in PIT, i.e. the taxation of dividends and financial capital gains. 


\section{BINOMIAL PROBIT REGRESSION RESULTS FOR ECONOMIC VIEWS IN THE FB\&H}

Again, similar to the US and Croatian surveys (Lim, Slemrod and Wilking 2013, Šimović, Blažić and Štambuk 2014), binomial probit regression was conducted in order to determine taxpayers' behaviour and tax incidence. Statements 30 and 31 were used as behavioural predictors, and statements 26 and 27 as incidence predictors. Table 7 summarises the responses in terms of economic views.
Table 7, shows, similarly to the Croatian survey, that statement No. 31 (Different government tax reductions (reliefs, incentives) promote economic growth) turned out to be the best predictor among behavioural responses. The experts who answered positively (compared to those who answered negatively) to the aforementioned statement are more likely to be more inclined to an increase in standard VAT rates as well as excise duties on tobacco and tobacco products. The statement regarding an increase in standard VAT rates

Table 7: Binomial Probit Regression Results for Economic Views in the FB\&H

\begin{tabular}{|c|c|c|c|c|c|}
\hline \multirow[b]{2}{*}{ Question/Statement } & \multicolumn{2}{|c|}{ Behavioural responses } & \multicolumn{2}{|c|}{ Incidence } & \multirow[b]{2}{*}{$x^{2} \mathrm{e}$} \\
\hline & Q30a & Q31b & Q26c & Q27d & \\
\hline \multirow[t]{2}{*}{ Q01. B\&H should introduce reduced VAT rate. } & -0.194 & 0.239 & -0.248 & -0.123 & 11253 \\
\hline & $(0.381)$ & $(0.412)$ & $(0.322)$ & $(0.354)$ & [0.188] \\
\hline \multirow[t]{2}{*}{ Q02. Standard VAT rate should be increased. } & -0.638 & $1.501^{* *}$ & 0.422 & 0.315 & 12768 \\
\hline & $(0.409)$ & $(0.591)$ & $(0.335)$ & $(0.397)$ & {$[0.12]$} \\
\hline \multirow{2}{*}{$\begin{array}{l}\text { Q13. Excise duties on tobacco and tobacco products } \\
\text { should be increased. }\end{array}$} & -0.744 & $1.664^{* * *}$ & -0.268 & 0.577 & 13491 \\
\hline & $(0.546)$ & $(0.584)$ & $(0.404)$ & $(0.445)$ & [0.096] \\
\hline \multirow{2}{*}{$\begin{array}{l}\text { Q19. Social security contributions should be increased at } \\
\text { all levels (Pension, Health, Unemployment). }\end{array}$} & 0.366 & -0.005 & 0.615 & -0.095 & 14756 \\
\hline & $(0.639)$ & $(0.703)$ & $(0.439)$ & $(0.353)$ & [0.064] \\
\hline \multirow[t]{2}{*}{ Q20. A financial transaction tax should be introduced. } & -0.597 & -0.92 & -0.515 & -0.492 & 17046 \\
\hline & $(0.417)$ & $(0.572)$ & $(0.34)$ & $(0.428)$ & {$[0.03]$} \\
\hline \multirow[t]{2}{*}{ Q21. A financial activities tax should be introduced. } & 0.13 & $-1.229^{*}$ & $-0.742^{* *}$ & 0.049 & 42025 \\
\hline & $(0.444)$ & $(0.685)$ & $(0.35)$ & $(0.368)$ & [0.007] \\
\hline \multirow{2}{*}{$\begin{array}{l}\text { Q23. General government should be financed less from } \\
\text { taxes and more from different non-tax revenues (with an } \\
\text { emphasis on different user charges). }\end{array}$} & -0.323 & 0.573 & 0.287 & 0.314 & 4099 \\
\hline & $(0.469)$ & $(0.476)$ & $(0.322)$ & $(0.335)$ & [0.848] \\
\hline \multirow{2}{*}{$\begin{array}{l}\text { Q39. Taxation should include other forms of property, too } \\
\text { (movable property, financial property, etc.), i.e. should be } \\
\text { a synthetic taxation of property (net wealth tax). }\end{array}$} & -0.239 & -0.165 & -0.362 & $0.909^{* *}$ & 10724 \\
\hline & $(0.442)$ & $(0.467)$ & $(0.326)$ & $(0.37)$ & [0.218] \\
\hline \multirow[t]{2}{*}{ Q41. Inheritances and gifts should be taxed. } & 0.237 & $-0.693^{*}$ & $-0.617^{* *}$ & $0.614^{*}$ & 13837 \\
\hline & $(0.378)$ & $(0.394)$ & $(0.313)$ & $(0.334)$ & [0.086] \\
\hline \multirow{2}{*}{$\begin{array}{l}\text { Q43. Property is a necessary additional indicator of abil- } \\
\text { ity to pay besides income. }\end{array}$} & -0.335 & -0.126 & -0.12 & 0.535 & 8577 \\
\hline & $(0.697)$ & $(0.752)$ & $(0.438)$ & $(0.427)$ & [0.379] \\
\hline \multirow[t]{2}{*}{ Q46. The FB\&H should introduce progressive income tax. } & 0.081 & 0.3 & -0.124 & $0.697^{* *}$ & 6861 \\
\hline & $(0.416)$ & $(0.458)$ & $(0.323)$ & $(0.327)$ & [0.552] \\
\hline \multirow{2}{*}{$\begin{array}{l}\text { Q47. Current personal income tax rate of } 10 \text { per cent } \\
\text { should be increased. }\end{array}$} & -0.355 & -0.074 & -0.104 & $1.135^{* *}$ & 16859 \\
\hline & $(0.495)$ & $(0.466)$ & $(0.398)$ & $(0.553)$ & [0.032] \\
\hline \multirow{2}{*}{$\begin{array}{l}\text { Q48. Personal allowances in personal income tax should } \\
\text { be abolished. }\end{array}$} & -0.431 & -0.568 & -0.199 & $1.109^{* * *}$ & 18682 \\
\hline & $(0.438)$ & $(0.508)$ & $(0.36)$ & $(0.427)$ & [0.017] \\
\hline \multirow[t]{2}{*}{ Q49. Family allowances should be abolished. } & -0.098 & -0.58 & -0.415 & 0.632 & 12551 \\
\hline & $(0.433)$ & $(0.501)$ & $(0.405)$ & $(0.413)$ & [0.128] \\
\hline \multirow{2}{*}{$\begin{array}{l}\text { Q50. Tax deductions/allowances for health costs should } \\
\text { be abolished. }\end{array}$} & -0.227 & -0.118 & -0.194 & $0.825^{* *}$ & 21762 \\
\hline & $(0.446)$ & $(0.514)$ & $(0.369)$ & $(0.418)$ & [0.005] \\
\hline \multirow{2}{*}{$\begin{array}{l}\text { Q51. Tax deductions/allowances for owner-occupied } \\
\text { housing should be abolished. }\end{array}$} & -0.532 & 0.175 & -0.507 & $0.734^{*}$ & 18915 \\
\hline & $(0.431)$ & $(0.475)$ & $(0.329)$ & $(0.38)$ & [0.015] \\
\hline
\end{tabular}




\begin{tabular}{|c|c|c|c|c|c|}
\hline \multirow[t]{2}{*}{ Q53. Inside PIT, dividends should be taxed. } & -0.687 & 0.211 & -0.388 & 0.372 & 10703 \\
\hline & $(0.441)$ & $(0.44)$ & $(0.304)$ & $(0.342)$ & [0.219] \\
\hline \multirow[t]{2}{*}{ Q54. Inside PIT, financial capital gains should be taxed. } & -0.789 & -0.783 & -0.181 & 0.553 & 16303 \\
\hline & $(0.505)$ & $(0.618)$ & $(0.327)$ & $(0.352)$ & [0.038] \\
\hline \multirow{2}{*}{$\begin{array}{l}\text { Q55. Inside PIT, interest on saving and securities should } \\
\text { be taxed. }\end{array}$} & -0.208 & 0.121 & -0.248 & $1.478^{* * *}$ & 21086 \\
\hline & $(0.408)$ & $(0.417)$ & $(0.372)$ & $(0.473)$ & [0.007] \\
\hline \multirow{2}{*}{$\begin{array}{l}\text { Q56. All sources of income inside PIT should be taxed in } \\
\text { the same way (at statutory rates, without allowing the } \\
\text { lower withholding tax to be the final tax due). }\end{array}$} & 0.704 & 0.02 & 0.136 & -0.234 & 25448 \\
\hline & $(0.48)$ & $(0.494)$ & $(0.353)$ & $(0.405)$ & [0.001] \\
\hline \multirow{2}{*}{$\begin{array}{l}\text { Q57. Capital incomes should be taxed at lower rates than } \\
\text { labour incomes. }\end{array}$} & $1.166^{* *}$ & 0.301 & $0.753^{* *}$ & 0.192 & 18165 \\
\hline & $(0.486)$ & $(0.538)$ & $(0.375)$ & $(0.391)$ & {$[0.02]$} \\
\hline \multirow{2}{*}{$\begin{array}{l}\text { Q58. Dividends should be taxed at lower rates than } \\
\text { other incomes (due to the economic double taxation of } \\
\text { dividends). }\end{array}$} & 0.461 & 0.48 & 0.47 & -0.56 & 8391 \\
\hline & $(0.378)$ & $(0.428)$ & $(0.323)$ & $(0.357)$ & [0.396] \\
\hline \multirow{2}{*}{$\begin{array}{l}\text { Q59. Compensation of employees (i.e. fringe benefits) } \\
\text { should continue to be exempt from taxation on income. }\end{array}$} & 0.531 & 0.653 & -0.064 & -0.498 & 18256 \\
\hline & $(0.376)$ & $(0.406)$ & $(0.378)$ & $(0.41)$ & [0.019] \\
\hline \multirow[b]{2}{*}{ Q61. The corporate income tax rate should be increased. } & $-1.433^{* * *}$ & 0.61 & -0.478 & 0.428 & 17371 \\
\hline & $(0.458)$ & $(0.507)$ & $(0.374)$ & $(0.377)$ & [0.026] \\
\hline \multirow{2}{*}{$\begin{array}{l}\text { Q62. Differentiated / reduced corporate income tax rates } \\
\text { should be introduced for certain industries (e.g. agricul- } \\
\text { ture, tourism). }\end{array}$} & -0.355 & $0.904^{* *}$ & 0.24 & -0.054 & 6406 \\
\hline & $(0.412)$ & $(0.434)$ & $(0.328)$ & $(0.344)$ & [0.602] \\
\hline \multirow[b]{2}{*}{ Q64. Reinvested profits should be exempt from taxation. } & -0.363 & $1.582^{* * * *}$ & -0.021 & 0.238 & 14033 \\
\hline & $(0.47)$ & $(0.514)$ & $(0.354)$ & $(0.368)$ & {$[0.081]$} \\
\hline
\end{tabular}

Notes: Robust standard errors are in parenthesis. The $p$-values of the $x^{2}$ are in brackets. Other regressors include indicators of sector of employment, age and education.

${ }^{*} \mathrm{p}<0.1 ;{ }^{* *} \mathrm{p}<0.05 ;{ }^{* * *} \mathrm{p}<0.01$

${ }^{\mathrm{Q}} \mathrm{Q} 26$. The tax burden should be shifted from personal and corporate income to consumption.

${ }^{b} \mathrm{Q} 27$. The tax burden should be shifted from personal and corporate income to property.

'Q30. Non-taxation of financial capital gains encourages investment and promotes economic growth.

${ }^{\mathrm{Q} Q 31}$. Different government tax reductions (reliefs, incentives) promote economic growth.

Source: Authors' calculations.

could be justified as a revenue compensating measure caused by increasing tax expenditures. Hence, those who responded positively to statement 31 are also likely to answer positively in terms of the introduction of reduced corporate income tax rates for certain industries and the exemption of reinvested profits from taxation. Those more inclined to tax reductions as a way of promoting economic growth are more likely to respond negatively to an introduction of financial activities tax as well as the taxation of inheritances and gifts. Again, responses show inconsistencies which could only be linked to fragmented tax policy within the FB\&H, where comprehensiveness of tax reforms is unfortunately not considered. The possible introduction of a financial activities tax would probably be under the jurisdiction of the FB\&H, whereas the taxation of inheritances and gifts is currently under cantonal jurisdiction (ten separate laws in each canton within the FB\&H).
Statement No. 30 (Non-taxation of financial capital gains encourages investment and promotes economic growth) as a narrower statement proved to be a less important predictor (similar to Šimović, Blažić and Štambuk 2014). Those who answered positively to this statement (compared to those who answered negatively) are more likely to be against an increase in corporate income tax. This is an expected answer from those who are more inclined to neo-liberal ideology. Although responses are not statistically significant, statements regarding taxation of dividends, financial capital gains and interest on saving and securities have a negative relationship to the aforementioned statement, which is again a logical response of the more liberal experts.

Statement No. 27 (The tax burden should be shifted from personal and corporate income to property) turned out to be a more important predictor than statement 26 regarding a shift in tax burden 
from personal and corporate income to consumption. Expectedly, those who answered statement 27 positively (compared to those who answered negatively) are more likely to favour a more comprehensive definition of taxation of property (statement No. 39). Moreover, respondents who answered positively to statement No. 27 are also more inclined to answer positively to the taxation of inheritance and gifts, the introduction of progressive PIT and an increase in the current 10 per cent PIT rate. Therefore, with base-broadening measures together with the introduction of progressive PIT (or an increase in 'flat tax'), experts are more in favour of comprehensive income tax under the S-H-S definition. This is very similar to responses in the Croatian survey (Šimović, Blažić and Štambuk 2014). However, what seems to be an unexpected response is that this group favours the abolishment of personal allowances (statement No. 48), and tax deductions for health costs (statement No. 50). These responses are not expected, since the $\mathrm{S}-\mathrm{H}-\mathrm{S}$ definition of income acknowledges personal allowances as standard allowances. Property is usually perceived as an additional indicator of the ability to pay besides income, and nowadays, in the 'hybrid' definition of income as tax base different sources of property (and property rights) are included in the income tax base. However, personal allowances are usually kept, although in some transition countries (e.g. Bulgaria, Georgia), they are abolished under the 'flat tax'. Those in favour of a shift from income to property are also more likely to answer positively regarding the taxation of interest on savings and securities.

\section{CONCLUSION}

This paper attempted to summarise the major results of a survey regarding tax policy issues and attitudes in B\&H. Furthermore, the results from a similar survey conducted in the RS were compared with the FB\&H case. Thus, even though B\&H tax policy is conducted separately, the majority of respondents in both entities share common feelings regarding most tax policy issues. Differences amongst entities that do exist mostly relate to statements regarding the introduction of reduced VAT rates and preference in terms of the efficiency-equity trade-off. Interestingly enough, with the current $\mathrm{B} \& \mathrm{H}$ application of single rate broad-based VAT, most of the experts in both entities think that the VAT is not regressive. The FB\&H survey also showed a very high degree of consensus among most statements about experts' attitudes. This is a surprising fact, especially under the current divided markets and complex tax policy. However, as we argued before, the FB\&H survey showed a few inconsistencies in its responses, especially those related to general tax issues and economic models. Moreover, the greatest differences in responses between the entities occurred in this part of the survey.

The results of binomial probit regression in the FB\&H regarding economic values were evaluated using two predictors: one promoting lesser, and the other promoting greater government intervention. The results were mostly expected (i.e. introduction of financial activities tax or lesser government financing from taxes, and more from different non-tax revenues). However, other results in the FB\&H in terms of economic values are sometimes unclear, with numerous unexpected answers. Similarly, binomial probit regression for economic views provided similar unclear responses. The reason might be the fact that tax reforms in (F)B\&H are adopted ad hoc and under pressure from the international community, and therefore, local tax experts have little knowledge regarding specific tax issues (i.e. comprehensiveness of income or consumption as a tax base); the second point builds on the first regarding the crucial definition of the tax base in terms of its broadness (or narrowness), especially in PIT, i.e. the taxation of dividends and financial capital gains. Similarly inconsistent responses could be found in the FB\&H indicating an unclear direction for tax reforms. Hence, in the twenty years since the end of the war in $\mathrm{B} \& \mathrm{H}$, tax reforms were adopted either ad hoc or under pressure from the international community, which is in turn reflected in the unclear direction of tax policy in (F)B\&H.

\section{References}

Antić, D. 2014 (September). Anketa o poreznom sistemu i poreznoj politici BiH. [Opinion survey about tax system and tax policy]. Porezni savjetnik. 14-24.

B\&H Directorate for Economic Planning. 2012. Annual Economic Report - Economic Trends for Years 2004-2012. Council of Ministers of B\&H. http://dep.gov.ba/dep_publikacije/ekonomski_trendovi/Archive.aspx?langTag=bsBA\&template_id=140\&pagelndex=1 (accessed: July 21, 2013).

DeGroat, B. 2013. What do Tax Policy Experts Think About U.S. Tax Policy? Michigan News, University of Michigan's Office of Tax Policy Research and the National Tax Association. http://ns.umich.edu/new/releases/21386what-do-tax-policy-experts-think-about-u-s-tax policy (accessed: October 10, 2014).

EUROSTAT. 2013. General Government Deficit (-) and Surplus (+) - Annual Data as \% of GDP. http://ec.europa. 
eu/eurostat/tgm/table.do?tab=table \&plugin=1\&langua ge=en\&pcode=teina200 (accessed: July 15, 2014).

Garnier, G., Gburzynska, A., György E., Mathé, M., Prammer, D., Ruà, S., \& Skonieczna, A. 2013. Recent Reforms of Tax Systems in the EU: Good and Bad News. Taxation papers. Working Paper No. 39. European Commission. http:// ec.europa.eu/taxation_customs/resources/documents/ taxation/gen_info/economic_analysis/tax_papers/taxation_paper_39.pdf (accessed: February 10, 2014).

Hadžiahmetović, A. 2005. Ekonomija Evrope. [European Economics]. Sarajevo: Ekonomski fakultet Sarajevo.

Indirect Tax Authority. 2014. Izvještaj o dužnicima po osnovu PDV-a na dan 02.07.2014. [Report on debtors for VAT on July 2, 2014]. http://www.uino.gov.ba/download/duznici/pdv\%20duznici.pdf (accessed: January 27, 2015).

Kapopoulos, P. and Lazareton, S. 2011. Fiscal Policy Stance And Debt Sustainability In SEE Countries: A Comparative Analysis. The South East European Journal of Economics and Business 6 (2): 55-66.

Klun, M. 2014. Slovenian Experiences and Lessons from Tax Reforms. In Tax Reforms: Experiences and Perspectives, edited by H. Blažić, K. Ott, \& H. Šimović, 149-157. Zagreb: The Institute of Public Finance.

Kreso, S. 2005. Fiscal Decentralization in B\&H. Paper presented at the International Symposium: Bosnia and Herzegovina from Past to Present, Çanakkale Onsekiz Mart University, Çanakkale, April.

Kreso, S. and Lazović-Pita, L. 2013. Is Fiscal Discipline and Sustainability Strategy (FDSS) an Appropriate Option For $\mathrm{B} \& \mathrm{H}$ ? Paper presented at the 6th International Conference The Changing Economic Landscape: Issues, Implications and Policy Options, Juraj Dobrila University of Pula, Pula, May.

Lim, D., Slemrod, J., Wilking, E. 2013. Expert and Public Attitudes Towards Tax Policy: 2013, 1994, and 1934. National Tax Journal. 66 (4): 775-806.

Musgrave, R.A. and Musgrave P. 1993. Javne financije u teoriji i praksi. [Public finance in theory and practice]. Zagreb: Institut za Javne Financije.

OECD. 2010. Choosing a Broad Base - Low Rate Approach to Taxation. OECD Tax Policy Studies No. 19. Paris. OECD. DOI: 10.1787/9789264091320-en (accessed: May 5, 2011).

OECD. 2014. Taxing Wages 2014. Paris. OECD. DOI: 10.1787/ tax_wages-2014-en (accessed: April 25, 2015).

Official Gazette of B\&H. 2003. Decision on the Establishment of the Commission for the Indirect Tax Policy. Official Gazette of B\&H 4.

Schneider, F. 2012. The Shadow Economy and Work in the Shadow: What Do We (Not) Know? IZA DP No. 6423. http://ftp.iza.org/dp6423.pdf (accessed: July 15, 2013).

Šimović, H., Blažić, H., Štambuk, A. 2013. Što porezni stručnjaci misle o poreznom sustavu i poreznoj politici u Hrvatskoj? [What do tax experts think about Croatian tax system and tax policy?]. Porezni vjesnik. 22 (12): 31-37. http://www.ijf.hr/upload/files/file/PV/2013/12/simovic. pdf (accessed: April 20, 2014).

Šimović, H., Blažić, H., Štambuk, A. 2014. Perspectives of Tax Reforms in Croatia: Expert Opinion Survey. Financial Theory and Practice. 38 (4): 405-439. http://fintp.ijf.hr/ upload/files/ftp/2014/4/simovic_blazic_stambuk.pdf (accessed: January 20, 2015).

Slemrod, J. 1995. Professional Opinions About Tax Policy: 1994 and 1934. National Tax Journal. 48 (1): 121-147.

Tax Administration of FB\&H. 2014. Pregled poreznih obveznika sa iznosom duga po osnovu poreza, doprinosa, taksi i drugih naknada prema evidencijama kantonalnih poreznih ureda nadležnih ispostava na dan 28.02.2014. [Taxpayers debt status for taxes, contributions, fees and other fees according to the records of the cantonal tax offices on February 28, 2014 - a review]. Sarajevo. Tax administration of FB\&H.

Tax Administration of RS. 2014. Pregled stanja duga na dan 28. 02. 2014. [Debt Status on February 28, 2014 - a review]. Banja Luka. Tax administration of RS.

\section{(Endnotes)}

1 This work has been supported in part by the Croatian Science Foundation under the project number IP-201311-8174 and in part by the University of Rijeka under project number 13.02.1.2.02. We would like to thank Prof. dr Sead Kreso for his support during this project. Also, we would like to thank Mr. Midhat Arifović and Mrs. Aida Hakalović from the Tax Administration of the FB\&H for their engagement and willingness to expedite this survey. Authors would also like to thank the two anonymous referees for their useful suggestions.

2 The OHR, since the High Representative in B\&H proclaimed the unified "Law on Customs and Excise Duties" which provided a basis for further developments in the field of indirect taxation. The High Representative passed in February 2003 the Decision on the Establishment of the Commission for Indirect Taxation Policy (Official Gazette of B\&H, No. 4, 2003), pursuant to his powers and aimed at ensuring economic sustainability in $\mathrm{B} \& \mathrm{H}$.

3 Bachelor's degree includes those who successfully finished undergraduate studies of both the pre-Bologna and Bologna types. Similarly, master studies include postgraduate studies in the same manner.

4 The Likert scale was scaled as following: 1-strongly disagree, 2-disagree, 3-neutral, 4-agree and 5-strongly agree.

5 All responses are analysed and discussed in comparison to those respondents who answered negatively to the given statements. 